FATHERING IN CANADA: STILL WORK TO DO

\title{
A SURVEY AND DESCRIPTION OF PROJECTS THAT SUPPORT AND PROMOTE FATHERING IN CANADA: STILL WORK TO DO TO REACH FATHERS IN THEIR REAL-LIFE SETTINGS
}

\author{
ANNIE DEVAULT, \\ Université du Québec en Outaouais \\ JUDITH GAUDET, CHRISTINE BOLTE, and MICHÈLE ST-DENIS \\ Université du Québec à Montréal
}

\begin{abstract}
This study aimed to identify the characteristics of current Canadian intervention programs designed to support father involvement. Sixty-one projects in the 10 provinces constituted the sample. Results show that most of the projects operate on limited budgets. The activities they offer mostly target fathers themselves to the exclusion of key people in their social environment. The discussion underscores the strenghts and weaknesses of father support programs, and guidelines for future intervention in this area are proposed.
\end{abstract}

It is generally recognized today that children benefit from the presence of their father. Compared to children whose father is absent, those who maintain relations with him benefit affectively, cognitively, and morally, and make gains in the development of social skills and sexual identity (Amato \& Gilbreth, 1999; Lamb, 2004). In contrast, the absence of the father, or his weak level of participation, is associated with depressive symptoms, behavioural difficulties, and low self-esteem in children (Phares, 1999). Even though it cannot be established with certainty whether these symptoms are associated with the father's absence or with the conditions of single parenting, research tends to show that, overall, children who are close to their father, rather than removed from him, display a better course of development. A connection has also been established between the father's sense of competence and the prevention of negligence towards children (Dubowitz, Black, Kerr, Starr, \& Harrington, 2000).

It has also been established that today's fathers are more involved than their own were (Pleck, 1997). Changes in the nature of the family, structurally and functionally, have had major impacts on the father's role. Single fathering and, in the case of joint custody, sharing the care and education of children when the mother works full-time, as well as alterations in gender and parental roles in general, have all increased the tendency among many fathers to invest more in their children. An American study shows that fathers who divorced during the 90s were more involved with their children than divorced fathers from the 80s (Hetherington \& Kelly, 2002). Still, a large number of children gradually lose contact with their father, particularly following the separation of their parents (Marcil-Gratton \& Le Bourdais, 1999).

The positive impact of fathers' involvement with their children, their desire to get involved even though they have not been socialized to assume the care and 
education of children, and some fathers' loss of contact with their children pursuant to divorce are all phenomena that justify the establishment of support mechanisms for fathers. Some interest groups exist in Ontario with FI-ION (Father Involvement Initiative Ontario Network) and in Québec with Prospère. There are also a number of Canadian researchers concerned with fathering issues; a recent literature review identified 71 researchers in Canada whose research is relevant to intervention (Dubeau, 2002). But, unfortunately, little information is available with regard to the existence of such programs of intervention in Canada. The purpose of this paper is to fill this gap in the literature. From a survey conducted in Canada, we present an overview of existing programs that are known to sustain and encourage the involvement of fathers.

\section{INTERVENTION PROGRAMS FOR FATHERS}

Early intervention programs for children and their families assign priority to the participation of parents. As the first agents of socialization, parents have an undeniable influence in promoting young children's well-being and in preventing problems from arising. If in theory parents are an integral part of the intervention and prevention practices that target children and their families, in practice the actual participation of fathers is quite low (Phares, 1999; Summers, Boller, \& Raikes, 2004). From the very start, the great majority of programs for teaching parenting skills have targeted mothers (Durning, 1995). These programs are designed for women and taught by women. Reasons for this might include the belief that mothers are more competent in areas regarding the development of children and the fact that mothers are often more available to participate when they are home with young children.

There are more intervention programs designed for fathers today than there were 25 years ago (Arama \& Bouchard, 1996; Dulac, 1996; Levine, Murphy \& Wilson, 1993), but unfortunately, little evaluative data are currently available as to the effectiveness of these programs (Cabrera \& Peters, 2000; Smith, Buzy, \& Weinman, 2002). However, the results from the few existing impact evaluation studies indicate positive effects stemming from paternal involvement (Palm \& Palkowitz, 1988). For example, fathers who participated in the Head Start program made significant gains in terms of direct interactions, accessibility, and support for learning when they were in the presence of their children (Fagan \& Iglesias, 1999). Among fathers of newborn babies from disadvantaged environments, an intervention as short as three hours had a positive effect on their capacity to hold their newborn, nourish her or him, and respond to the stimuli emitted by the baby in a more synchronized, tender, and adequate manner than the fathers from a control group (Pfannenenstiel \& Honig, 1991). Other qualitative studies show that mutual help and support groups helped divorced fathers to cope with their stress, to diminish their feelings of loneliness (Karp, 2000), to develop insight, and to learn new parental skills more tailored to their child's age and needs (Anderson, Kohler, \& Letiecq, 2002; Frieman, 2002). Unfortunately, researchers have also reported difficulty recruiting fathers and maintaining their consistent participation, a problem that exists in Canada as much as in the United States (Arama \& Bouchard, 1996; Dulac, 1996; Fagan \& Iglesias, 1999).

Analysis of American programs indicates that their two primary objectives are to increase the fathers' knowledge about child development and to improve their individual skills. The programs have largely taken the form of mutual help or 
educational groups similar to those offered to mothers. Such programs respond to the needs of certain fathers who, due to their socialization, and the absence of models, do not feel ready to assume their parenthood. Educational or informational support may, therefore, encourage their involvment (Levine et al., 1993).

The focus of the interventions on the fathers themselves and on their acquisition of skills and knowledge can be to the detriment of understanding the context in which problems occur. In other words, as with programs targeting mothers, there are few that integrate ecological dimensions while promoting both educational objectives and institutional and cultural change (Dubeau, Turcotte, \& Coutu, 1999). Moreover, there seems to have been no systematic effort to document other forms of intervention that do not solely target fathers.

\section{SURVEY OBJECTIVES AND THEORETICAL FRAMEWORK}

What is original about the present survey is the effort to present an overall picture of Canadian intervention programs for fathers which, following the ecological model developed by Bronfenbrenner (1979; Bronfenbrenner \& Morris, 1997), takes into account the many dimensions involved in the promotion of paternal involvement: namely, the father himself, the family, the father's environment, and the larger society. This model had a considerable influence on the choice of projects, the construction of tools for carrying out the survey, and the analysis of results.

The ecological analysis of projects looks at the diversity of elements taken into account during the intervention. Some projects emphasize skills or knowledge acquisition by fathers (the ontosystem). Others deal more with changes in the fathers' environments, for example, projects that encourage mothers to promote paternal involvement or that increase the sensitivity and openness of schools and social workers towards fathers' needs (the microsystem). Other projects aim to improve the compatibility between fathers' various environments and aim to improve access to family services for fathers who work full-time or who have their children only on weekends, by extending the hours during which such services are available (the mesosystem). Other initiatives, more political, lobby to change child custody or parental leave policies (the exosystem) while others plan mass information campaigns in order to influence public opinion towards fathers (the macrosystem). Finally, the ages of both children and fathers influence the strategies and implementation of certain projects (the chronosystem).

\section{METHOD}

\section{The Survey Tool}

The main objective of the data collection questionnaire was to draw up a precise description of projects and the conditions in which they operated. Various project evaluation studies provided the scientific basis for choosing the type of data to collect (Arama \& Bouchard, 1996; Blanchet et al., 1993; Chamberland et al., 2000; Groupe de travail pour les jeunes, 1991; O’Loughlin et al., 1998; Turcotte, 1994). The questionnaire was drafted in French and translated into English, verified by five researchers, and pre-tested by six project managers who spoke both English and French. This procedure allowed the number of questions to be reduced and their content and presentation to be clarified. 
The final version of the questionnaire included several general questions-basic information about the project, name of the project manager, moment of implementation-and a set of questions designed to reveal the main characteristics of the project-region, initiators, general objectives, activity targets, project team, funding sources, partners, observed effects, obstacles, evaluation, and, most noteworthy, project activity. The questionnaire included questions in both multiple-choice and short-answer formats.

\section{Data Collection}

The first step in the data collection was to locate the projects. We looked for projects-initiatives, resources, programs, etc.- that sought to promote the involvement of fathers with children aged 0 to 12 years. We began by gathering information from key sources working in a wide range of family-oriented sectors throughout Canada. As a result of their assistance, we obtained contact information for about 230 projects.

The questionnaire and a letter explaining the selection procedure were mailed to the project directors or coordinators of the 230 projects. There was a telephone follow-up three weeks after the mailing. Eighty-five questionnaires (37\% of the projects inventoried) were filled in and returned. Twenty-four projects were excluded based on a variety of criteria: incomplete questionnaires, projects oriented primarily towards the family with minimal emphasis on the father, or suspended projects. Thus, the final sample consisted of 61 projects.

\section{Data Analysis}

The data were coded according to the type of question. For multiple-choice questions, the categories were pre-defined. They were either nominal (e.g., the various sources of project funding) or numerical (e.g., the number of months since project inception). Data were entered into a spreadsheet and then sent on to SPSS. For short-answer questions, the thematic content of the responses was analyzed (Bardin, 1996). By grouping similar responses to each question from 15 of the questionnaires (20\% of the material), we were able to create a preliminary classificatory grid. This grid was then refined and applied to the 46 other questionnaires by adding and fusing categories constructed during the preliminary analysis. The rules of mutual exclusion and of the homogeneity of categories were respected. An external coder validated the classificatory grid in order to offset the main coder's biases, leading to a consensus on the categories that were adopted (Patton, 1987).

\section{RESULTS}

Due to length constraints, we will summarize the results of the survey describing the distribution of projects by province, their operational budgets, the project initiators, teams, and partners, and the activities and obstacles that they faced.

The 61 projects were concentrated primarily in three provinces (Figure 1) and were spread equally between the two official languages. Nearly half the projects (48\%) were based in cities, $12 \%$ operated in suburbs, another $12 \%$ in rural areas, and the 16 remaining projects had activities in more than one area. 


\section{FATHERING IN CANADA: STILL WORK TO DO}

The mean lifespan of the projects was about three years (37.5 months), not a great length of time to initiate activities and become known. There were exceptions, however, with one project having operated for nearly 15 years. The distribution of

\section{FIGURE 1}

Project Distribution by Province

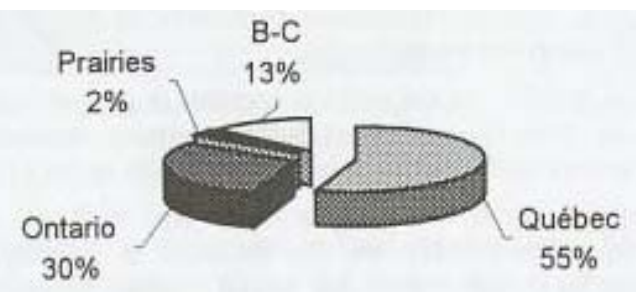

project existence was the following: less than 2 years: $44 \%$; $2-4$ years: $31 \%$; more than 4 years: $25 \%$.

The survey revealed that most projects operated on extremely tight budgets. Of the 48 respondents who provided funding information, 37\% declared annual budgets of less than $\$ 2,000$, and $62 \%$ functioned on less than $\$ 10,000 /$ year. The mean annual project budget was $\$ 13,000$.

Not only were these amounts low, the security of the funding was also extremely precarious. When asked how long they could count on their funding, $41 \%$ of the project managers replied that it was simply not secure. Thirteen percent (13\%) said that their budget was secure for less than one year. Combining these results revealed that more than half the projects had secure funding for less than one year. Twentytwo percent (22\%) had a budget secured for one year, $16 \%$ for $2-5$ years, and only $9 \%$ for 5 years.

People from diverse backgrounds can get involved in setting up projects that promote and support paternal involvement: a group of fathers, public service workers, the director of a community organization or some other establishment, a research team, a funding agency, or a government. Most of the projects inventoried appeared to have been established through the initiatives of people with close ties to the com-

FIGURE 2

Distribution of Type of Partnership Organization

\begin{tabular}{lc}
\hline Type of Partnership Organization & \% \\
\hline Health of social services organizations & 40 \\
Community organizations & 25 \\
Schools or daycare centers & 15 \\
Universities or research groups & 7 \\
Municipalities & 6 \\
Private sector & 4 \\
Other & 3 \\
\hline
\end{tabular}


munity (fathers, practitioners) rather than by such people as directors of organizations (community or public).

In total, the 61 projects inventoried employed 220 people. Project teams averaged five people; however, nearly half the projects functioned with small teams of one to three people. Men comprised $60 \%$ of the project workers. On the average, project workers had 13 years of experience in the field of social services. Most came from the community sector (33\%), the public health and social service sector (27\%), or the private sector (18\%). As many as $80 \%$ had a university education. Nearly all (94\%) were employed on a part-time basis; $60 \%$ were salaried and $40 \%$ worked as volunteers, $80 \%$ of whom were men.

We also found that $92 \%$ of the projects operated in partnership with one or two other bodies. As shown in Figure 2, most of these partners were either in the public health and social service sector (40\%) or in the community sector (25\%).

The frequency of contact with partners varied from weekly to once a year. The most frequent form of partnership was the exchange of information. Only infrequently did projects forge partnerships that shared responsibilities or organized joint activities.

\section{Project Activities}

Some projects offered only one activity while others offered many. Activities ranged from group discussions to outings in the forest, family celebrations, and practitioner training. We documented 162 activities offered by the 61 projects. Most projects offered one or two activities, but one third offered a wider variety (Figure 3).

\section{FIGURE 3}

Number of Activities per Project

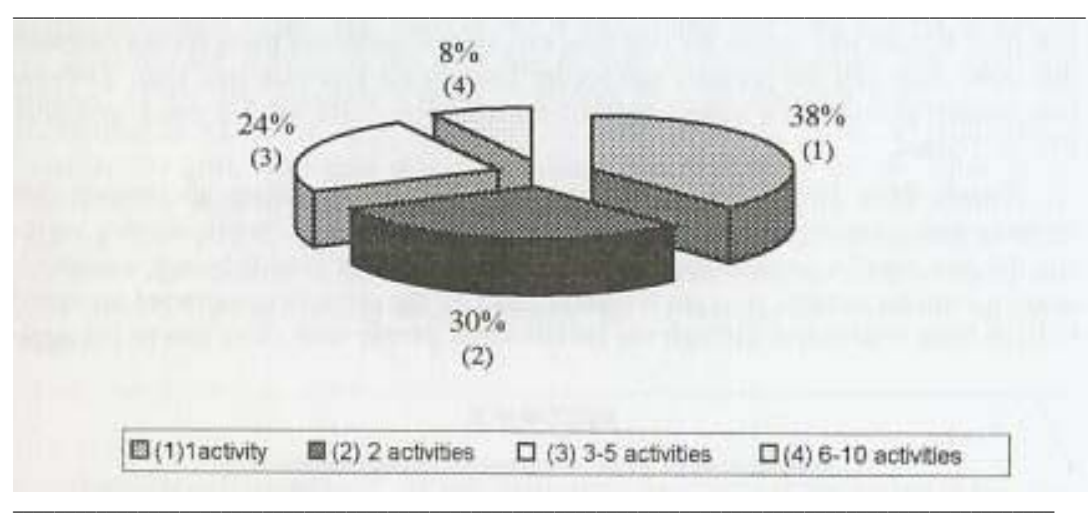

\section{Targets of the Activities}

The projects presented are grouped-using the systemic levels in the ecological approach-into three categories or targets of intervention. The category fathers and their families includes activities aimed at fathers only or at fathers and their children and/or spouses. The category fathers and their immediate environments comprises activities aimed at changing social practices and/or the fathers' environments. The category fathers and the larger environment is made up of activities directed at 


\section{FIGURE 4}

Number of Activities per Target (162 activities)

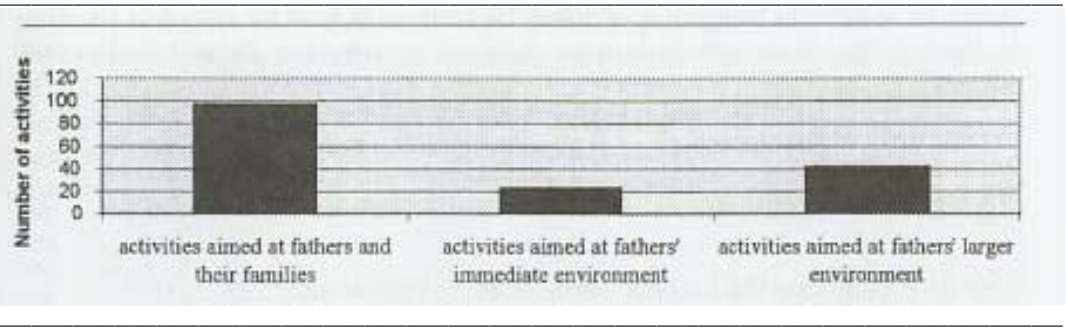

changing the population's social and cultural environments by means of mass influence. From this division, we found that the majority of projects had one target (61\%), 29\% had two, and only 10\% three targets.

Among the 61 projects inventoried, $60 \%$ of the activities (91 of the 162) targeted the father and his family, 14\% (23/162) targeted the environments in which the fathers lived, and 26\% (42/162) targeted the larger environment (Figure 4). The following section explains the nature of the activities in relation to the target.

\section{Activities Targeting Fathers and Their Families}

A closer look at the category fathers and their families reveals that a large proportion of activities concerned fathers exclusively (Figure 5). These activities had mainly two objectives: first, to promote and strengthen mutual support between fathers and, second, to help fathers better understand their role and to focus on their strengths. The first objective was met by support groups for fathers and the second by group workshops in which fathers and facilitators discussed child education and the father's role. Many of these activities provided fathers the opportunity to discuss such issues as their identities as fathers, their sense of parental competence, and the difficulties and joys of fatherhood.

\section{FIGURE 5}

Focus of Activities Targeting "Fathers and Their Families"

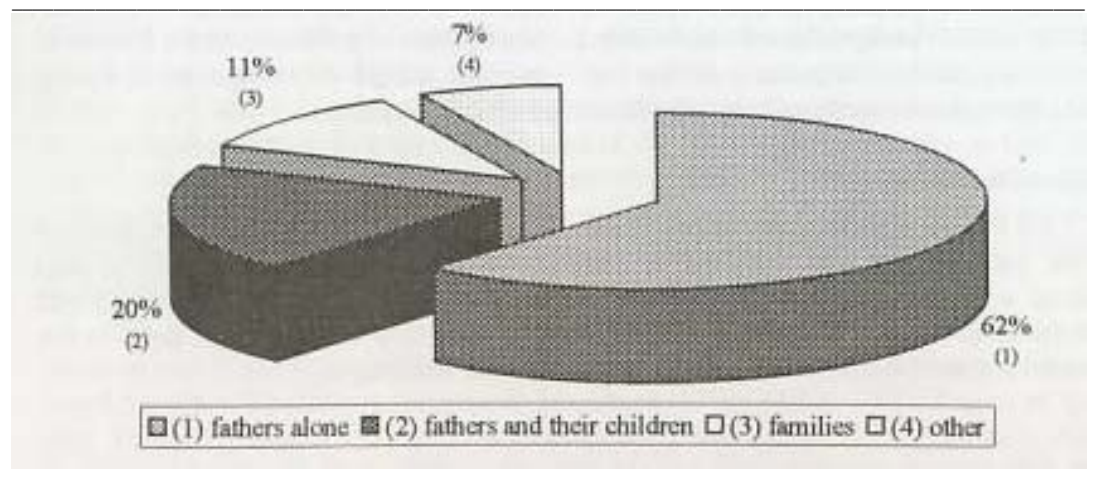


Some projects broadened their scope to include other family members. These projects offered activities for fathers accompanied by their children (20\%), permitting them to interact as well as observe other fathers interacting with their children. They often took the form of cultural outings or other activities of a more "hands-on" nature. In addition to being an opportunity for children to have the complete attention of their father, these activities were designed to reinforce fathers' feelings of competence. In some cases, albeit infrequently, the goals of the activity led to inclusion of the entire family rather than fathers alone (11\%) even though the primary focus was on father involvement. Such projects provided support for both parents, making use of communication workshops for young parents or family-oriented activities.

\section{Activities Targeting the Fathers' Immediate Environments}

Note in Figure 4 that $14 \%$ of the activities sought to bring about changes in the social practices of project staff or in their work environments. In these instances, the goals were essentially to ensure that when fathers went to community or social service centers, they would be treated warmly and benefit from services that considered their needs. There were two kinds of activities. The first type had the purpose of facilitating changes in the social practices of project staff, or in their work environments in order to adapt to fathers' needs. Workshops on intervention with fathers were designed for practitioners to make them think about how fathers collectively are treated in various organizations. The second type of activity was designed to offer direct support to practitioners who wanted to start a project with fathers and included support and discussion groups for practitioners working with fathers.

\section{Activities Targeting Fathers' Larger Environment}

The goal of some projects (26\%) was to bring about a change in the laws that directly affect fathers' lives. For instance, the associations for divorced fathers spent more energy on gaining political representation than other groups. They lobbied to change the standards, rules, and practices that govern the way child custody is awarded. Other ways to bring about changes in the larger environment include changing family mediation practices or by trying to alter the public image of fathers via electronic media or newsprint. Some chose to use the media to get their messages across, others took part in radio interviews or presented videos for debate and discussion. One group published information bulletins for fathers and the general public. Other mass-information campaigns consisted of organizing special events such as large, family-oriented celebrations, open houses, or public lectures. Events to which the entire community is invited have the added advantage of fostering interpersonal relationships between fathers in real-life situations.

\section{Major Obstacles}

As Figure 6 shows, the major obstacles encountered by all projects concerned father participation and the lack of financial support from local, provincial and federal agencies. Some project agents also pointed out that they had encountered resistance toward working with men and that the negative image of men held by the general population and certain social services posed challenges. 


\section{FIGURE 6}

Major Obstacles Faced by Projects $(n=61)$

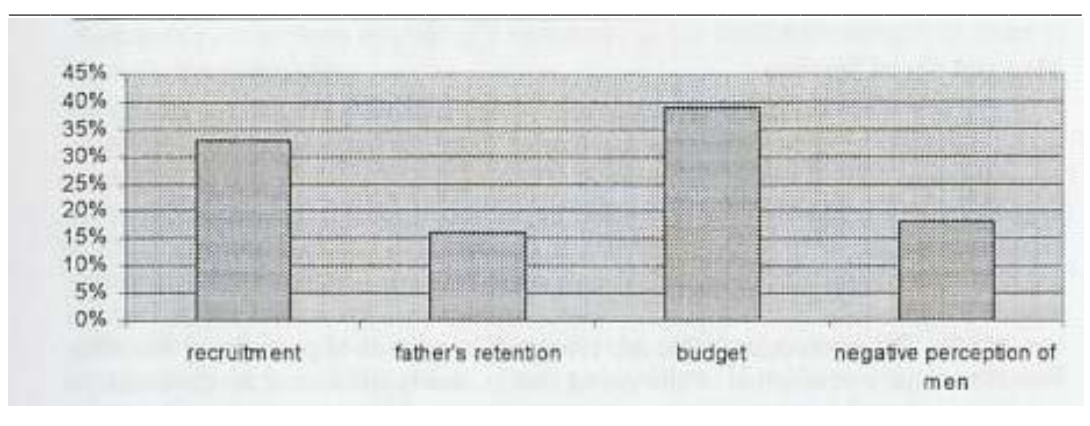

\section{DISCUSSION}

Despite some limitations of the study - the fact that not all provinces are equally represented and the use of a questionnaire that may not capture the qualitative details of the program intervention - the findings of this survey are valuable to the Canadian literature because it is the first time that a survey of this kind has been conducted. Throughout the discussion, and with support from the literature, we analyze the obstacles faced by projects and suggest how interventions for fathers can be improved in the future.

The survey shows that, financially, fathering projects are still a largely neglected area of intervention. In fact, budget is identified as the number one obstacle (see Figure 6). Other studies confirm these claims (Dulac, 1997). While it is more and more recognized and valued at an ideological level that fathers should be included in family intervention and that projects supporting paternal involvement should be established, much remains to be done concretely to bring such projects to life. For example, despite an explicit statement valuing the role of the father in Québec's National Priorities of Public Health (Ministère de la santé et des services sociaux du Québec, 1997), the projects underway in this province, though more numerous than elsewhere in Canada, suffer just as much from underfunding. Lack of money causes a series of obstacles: the difficulty in hiring people whose job would be to find different sources of financing; the chronic stress within the team; the disruption of the rhythm with which the project is carried out; the suspension of activities, especially during the summer, so that the expectations of the target clientele cannot be met; and, finally, the lack of funding preventing a project worker's permanent presence, even though it has been demonstrated that with a male clientele it is important to assure a stable presence and a continuity in services (Levine et al., 1993; McAllister, Wilson, \& Burton, 2004).

The second and third biggest obstacles faced by projects are recruitment and maintenance of the fathers' involvement in various programs. This difficulty has been noted by other researchers (Arama \& Bouchard, 1996; Dulac, 1997; Fagan \& Iglesias, 1999; Kiselica, 1995; Lane \& Cassandra, 2000; Turbiville \& Marquis, 2001; 
Weinman, Smith, \& Buzi, 2002). We did not ask the practitioners why they had problems recruiting fathers but the literature gives several reasons, including the fear of being judged for participating in such programs (Anderson et al., 2002), and fathers' availability due to work schedules, family obligations, or custody arrangements (Anderson et al., 2002; Raikes et al., 2002).

\section{Men and Social Services}

The last obstacle identified in this survey-the negative perception of men in the social services-can be related to the fear of negative judgement. Men are more reluctant than women are to call on social and community services that are available to them (Addis \& Mahalik, 2003), tending to perceive these resources as designed for women or for people in distress (Devault \& Gaudet, 2001). Indeed, their perceptions may be justified since there are still many programs for fathers designed in the same way as programs for mothers (Leitch, Gonzalez \& Ooms, 1993; see Lane \& Cassandra, 2000). The interventions that are proposed in support of parenthood are often biased towards a conception of the parent that is clearly influenced by the feminine model. The fact that a lot of programs are still designed for women suggest that the social services need to adapt their programs to male clientele. According to our survey, there is still resistance from some practitioners.

One way of facing this obstacle is to offer training to staff workers in the social services. Yet, as seen in this survey, the project workers are still rarely targeted in the intervention programs. Only 23 activities out of 162 were targeting practitioners. Few mesosystemic interventions bring about changes in the way project workers carry out their practice. Weinman and his colleagues (2002) have stated that there is sometimes a discrepancy between fathers' perceived needs and what the service providers might view as important for them. For example, a needs assessment conducted with 128 young fathers showed that a majority of them desired employment services and educational/vocational training but they did not want substance abuse counseling or child support services even if they showed certain risk behaviors. Training the staff workers may help practitioners be more sensitive to fathers' needs. An analysis of the successful strategies in working with fathers in an Early Head Start Program (McAllister et al., 2004) shows that project workers are a major part of this success by getting training in order to adapt their intervention to fathers.

Because of men's fear of being judged and their perception that social services are designed for women, it may be possible to increase recruitment by offering programs outside social and community services, however this is not currently the reality. Most of the intervention programs surveyed came out of institutional or community organizations in the health and social services network. In addition to being rarely visited by fathers, these services are largely staffed by female professionals, which can be a barrier for some fathers. Very few initiatives surveyed were integrated into the context of fathers' daily lives- the workplace or leisure centres—or children's daily lives, e.g., schools or daycare centres.

\section{Father Involvement Programs in the Workplace}

Another reason for problems recruiting fathers is their work schedule, leading to the question: What if we offered father involvement programs in the workplace? There is little doubt that support measures implemented at work would reach a much larger number of fathers. Currently, many researchers recognize the importance of actively soliciting fathers where they are and offering them activities tailored to their 
needs (Anderson et al., 2002; Fagan \& Iglesias, 1999; Raikes et al., 2002, Turbiville \& Marquis, 2001). Intervention in the work setting could also effectively addresss the multiple facets of the paternal role, including the reconciliation of work and family. In addition, the people in the fathers' environment, including colleagues and employers, would become more sensitive to the reality of fatherhood and, presumably, more open to making adjustments in the work environment in order to meet their requirements.

\section{Involving the Family}

Family obligations also have an impact on recruitment of fathers into programs. Involving the whole family in intervention may provide a solution. The majority of the projects surveyed, however, principally targeted the father, and less frequently the father and his family. Research shows that fathers prefer programs in which the whole family can participate. Results of two studies with fathers and their familiesone with a large sample of fathers $(\mathrm{N}=318)$ who participated in an early intervention Head Start program (Raikes et al., 2002) and another $(\mathrm{N}=220)$ with program staff (Turbiville \& Marquis, 2001)—show that fathers participate more in activities that target them, their children, and the whole family instead of them alone. Similarly, a number of other studies that simultaneously target the individual and his environment by means of a variety of intervention strategies clearly indicate that family programs are more effective than programs focusing on individuals (Dufour \& Chamberland, 2003; Groupe de travail pour les jeunes, 1991; Prilleltensky \& Nelson, 2000; Schorr \& Schorr, 1988). It is understandable that if a project targets fathers but does nothing to improve an environment that is not congenial to their participation, the objective is less likely to be attained.

\section{CONCLUSION}

Paternal involvement is a fairly recent area of interest, yet, in spite of limited resources, workers in the field have succeeded in developing intervention programs that support Canadian fathers. In this study most of the interventions aspired to knowledge acquisition and to mutual support among fathers, corresponding to what is known about intervention with mothers. However, literature on intervention with fathers shows that practitioners should broaden their scope of intervention. For instance, conditions of employment are still a major concern for most fathers and should be addressed in interventions (McAllister et al., 2004). Such an adaptation is necessary in order to assure that fathers participate and feel recognized and appreciated.

Despite the progress made during the last decade, much still remains to be done, especially in the direction of multiple intervention targets and impact evaluations of the projects (Smith, Buzi, \& Winman, 2002). We have seen that fathers are still the major targets of the interventions. Obviously, we are not proposing that fathers no longer be targeted, but that the people who surround them, beginning with the mothers, also be included. Interventions will be more successful if they target the fathers' environments - both immediate and extended-in order to promote father involvement not only to fathers but to people who surround them.

\section{RESUME}




\section{CANADIAN JOURNAL OF COMMUNITY MENTAL HEALTH}

Cette étude avait pour but d'identifier les caractéristiques des programmes de soutien à l'engagement paternel au Canada. Soixante et un projets issus des 10 provinces formaient l'échantillon. Les résultats montrent que la plupart des projets ont des budgets limités. Les activités qu'ils offrent sont principalement dirigées vers les pères. Peu d'activités rejoignent les individus dans l'environnement social des pères. La discussion met l'emphase sur les forces et les faiblesses des programmes de soutien à l'engagement paternel. Il propose des pistes pour l'intervention destinée aux pères.

\section{REFERENCES}

Addis, M.E., \& Mahalik, J.R. (2003). Men, masculinity and the contexts of help seeking. American Psychologist, 58, 5-14.

Amato, P.R., \& Gilbreth, J.G. (1999). Nonresident fathers and children's well-being. Journal of Marriage and the Family, 61, 557-573.

Anderson, E.A., Kohler, J.K., \& Letiecq, B.L. (2002). Low-income fathers and "Responsible Fatherhood” programs: A qualitative investigation of participants' experiences. Family Relations, 51, 148-155.

Arama, D., \& Bouchard, C. (1996). Recension des projets d'intervention ayant trait à la paternité dans la grande région de Montréal, Les cahiers d'analyse du GRAVE, 3, 1.

Bardin, L. (1996). L'analyse de contenu, $8^{\mathrm{e}}$ édition, Le psychologue, Paris, Presses universitaires de France.

Blanchet, L., Laurendeau, M.C., Paul, D., \& Saucier, J.-F. (1993). La prévention et la promotion en santé mentale: Préparer l'avenir. Boucherville, QC: Gaëtan Morin.

Bronfenbrenner, U. (1979). The ecology of human development: Experiments in nature and by design. Cambridge, MA: Harvard University Press.

Bronfenbrenner, U., \& Morris, P.A. (1997). The ecology of developmental processes. In W. Damon \& R.M. Lerner (Eds.), Handbook of child psychology. New York: John Wiley.

Cabrera, N., \& Peters, H.E. (2000). Public policies and father involvement. Marriage and Family Review, 29, 295-314.

Chamberland, C., Dallaire, N., Hébert, J., Fréchette, L., Lindsay, J., \& Cameron, S. (2000). Are social and ecological models influencing prevention practices? An overview of the state of affairs in Quebec for child, youth, and family interventions, Journal of Primary Prevention, 21(1), 101-117.

Devault, A., \& Gaudet, J. (2003). Le soutien aux pères biparentaux: l'omniprésence de " Docteur maman ». Service social, 50, 1-29.

Dubeau, D. (2002). Status of the research on fatherhood in Canada. Unpublished document.

Dubeau, D., Turcotte, G., \& Coutu, S. (1999). L'intégration des pères dans les pratiques d'intervention auprès des jeunes enfants et de leur famille. Revue Canadienne de psychoéducation, 28, 265-278.

Dubowitz, H., Black, M.M., Kerr, M.A., Starr, R.H., \& Harrington, D. (2000) Fathers and child neglect. Archives of Pediatric and Adolescence Medecine, 154, 135-141.

Dufour, S., \& Chamberland, C. (2003). L'efficacité des interventions en protection de l'enfance: Recension des écrits. Montréal: Centre d'excellence pour la protection et la bien-être des enfants.

Dulac, G. (1996). L'intervention auprès des pères: des défis pour les intervenants, des gains pour les hommes. Prisme, 18, 194-195.

Dulac, G (1997). Promotion du rôle des pères: revue de la littérature et analyse des impacts prévisibles. Montréal: Université Mc Gill, Centre d'études appliquées sur la famille.

Durning, P. (1995) L'éducation familiale. France: Presses universitaires de France.

Fagan, J., \& Iglesias, A. (1999). Father involvement program effects on fathers, father figures, and their head start children: A quasi-experimental study. Early Childhood Research Quarterly, 14, 243-269.

Frieman, B.B. (2002). Challenges faced by fathers in a divorce support group. Journal of Divorce and Remarriage, 37(1-2), 163-173.

Groupe de travail pour les jeunes. (1991). Un Québec fou de ses enfants. Quebec, QC: Ministère de la santé et des services sociaux du Québec. 
Hetherington, M.E., \& Kelly, J. (2002). For better or for worse: Divorce reconsidered. New York: W.W Norton \& Company.

Karp, L.J. (2000). Noncustodial fathers: Continued parent-child contact after divorce (Doctoral Thesis, Antioch University). Dissertation Abstracts International 60(6-A), 2242.

Kiselica, M.S. (1995). Multicultural counseling with teenage fathers: A practical guide. Thousand Oaks, CA: Sage.

Lamb, M.E. (2004). The role of the father in child development (4th ed.). New York: Wiley.

Lane, S.T., \& Cassandra, M.C. (2000). Meeting the service needs of young fathers. Child and Adolescent Social Work Journal, 17(1), 35-54.

Levine, J., Murphy, D., \& Wilson, S. (1993). Getting men involved: Strategies for early childhood programs. New York: Scholastic.

Marcil-Gratton, N., \& Le Bourdais, C. (1999). Garde des enfants, droits de visite et pension alimentaire: résultats tirés de l'Enquête longitudinale sur les enfants et les jeunes. Montréal: Centre interuniversitaire d'études démographiques, Université de Montréal/Institut national de la recherche scientifique.

McAllister, C.L., Wilson, P.C., \& Burton, J. (2004). From sports fans to nurturers: An early head start program's evolution toward father involvement. Fathering, 2, 31-59.

Ministère de la santé et des services sociaux. (1997). Priorités nationales de santé publique 1997-2002. Gouvernement du Québec.

O’Loughlin, J., Renaud, L., Richard, L., Gomez, L.S., \& Paradis, G. (1998). Correlates of the substainability of community-based hearth health promotion interventions, Preventive Medecine, 27, 702-712.

Palm, G., \& Palkowitz, R. (1988). The challenge of working with new fathers: Implications for support providers. In R. Palkowitz \& M. Sussman (Eds), Transitions to parenthood (pp. 357-376). New York: Haworth.

Patton, M.Q. (1987). How to use qualitative methods in evaluation. Thousand Oaks: Sage.

Pfannenstiel, A.E., \& Honig, A.S. (1991). Prenatal intervention and support for low-income fathers. Infant Mental Health Journal, 12, 103-115.

Phares, V. (1999). "Poppa" psychology. The role of fathers in children's mental well-being. Westport: Praeger.

Pleck, J.H. (1997). Paternal involvement: Levels, sources and consequences. In M.E. Lamb, (Ed.), The role of the father in child development ( $3^{\text {rd }}$ edition). New-York: Wiley.

Prilleltensky, I., \& Nelson, G. (2000). Promoting child and family wellness: Priorities for psychological and social interventions. Journal of Community and Applied Social Psychology, 10, 85-105.

Raikes, H., Boller, K., vanKammen, W., Summers, J., Raikes, A., Laible, D., Wilcox, B., Ontai, L., \& Christensen, L. (2002). Father involvement in early Head Start programs: A practitioners study. Mathematica Policy research, Princeton, NJ; Nebraska University, Lincoln; Gallup Organisation, Inc; Princeton NJ. Retrieved on April 6, 2004 from http://ccfl.edu/projets/pdf/Final_Father_Involvement

Schorr, L.B., \& Schorr, D. (1988). Within our reach: Breaking the cycle of disadvantage. New York: Anchor.

Smith, B.P., Buzy, S.R., \& Weinman, L.M. (2002). Programs for young fathers: Essential components and evaluation issues. North American Journal of Psychology, 4(1), 81-92.

Summers, J.A., Boller, K., \& Raikes, H. (2004). Preferences and perceptions about getting support expressed by low-income fathers. Fathering, 2, 61-82.

Turbiville, V.P., \& Marquis, J.G. (2001). Father participation in early education programs. Topics in Early Childhood Special Education, 21(4), 223-231.

Turcotte, G. (1994). L'implication paternelle: déterminants et modèles d'intervention, Les Cahiers du GRAVE 1, 4.

Weinman, M.L., Smith, P.B., \& Buzy, R.S. (2002). Young fathers: An analysis of risk behaviors and service needs. Child and Adolescent Social Work Journal, 19 (6), 437-453. 